\title{
GUIDELINES AND LEGAL ECOSYSTEM FOR THE CREATION OF ISLAMIC CONTENT IN MALAYSIA: TOWARDS CONSUMER EMPOWERMENT*
}

\author{
Adibah Ali** \\ Ida Madieha Abdul Ghani Azmi*** \\ Suzi Fadhilah Ismail ${ }^{* * * * *}$ \\ Mahyuddin Daud ${ }^{* * * * *}$ \\ Rokiah Alavi******
}

\begin{abstract}
The contents of the creative industry must portray the cultural and religious values of the country. As a tool of nation building, creative industry plays a fundamental role in inculcating good values and the avoidance of social illnesses. The objective of this study is to examine the importance and growth of Islamic contents in Malaysian creative industry. By employing qualitative research methods, namely, content analysis and interviews, the study found that there is increase in the
\end{abstract}

* This is a revised version of a paper presented at the $21^{\text {st }}$ MACFEA National Seminar "Consumer Services and Protection: Ensuring Sustainability", 1415 December 2017, International Islamic University of Malaysia, Malaysia. This paper and related research is funded by Ministry of Higher Education Malaysia (MOHE) via Fundamental Research Grant Scheme (FRGS). Acknowledgement is also for Mr. Ahmad Syazli Bin Muhd Khiar from FINAS for the guidance on the issue and the authors gratefully acknowledge the helpful guidance, comments and suggestions from the industry players, stakeholders and reviewers which has improved this article.

** MCL Student, Ahmad Ibrahim Kulliyyah of Laws, International Islamic University Malaysia, email: adibahali@iium.edu.my .

*** Professor, Civil Law Department, Ahmad Ibrahim Kulliyyah of Laws, International Islamic University Malaysia.

**** Assistant Professor, Civil Law Department, Ahmad Ibrahim Kulliyyah of Laws, International Islamic University Malaysia.

Assistant Professor, Civil Law Department, Ahmad Ibrahim Kulliyyah of Laws, International Islamic University Malaysia.

******* Professor, Kuliyyah of Economics and Management Sciences, International Islamic University Malaysia. 
demand for Islamic contents. This study intends to highlight some of the concerns raised by both producers and consumers of creative content with the hope of empowering consumers in choosing content that is more suitable to their cultural and religious needs. For the Islamic content industry to flourish, having a supportive legal ecosystem is imperative. This study explores the existing guidelines on Islamic content as a well as relevant legislation that governs content creation in Malaysia. The study concludes with some policy recommendations that would assist in harnessing the creation of Islamic content in Malaysia.

Keywords: consumer empowerment, creative industry, content creation, Islamic values, Islamic creative contents

\title{
GARIS PANDUAN DAN EKOSISTEM UNDANG-UNDANG BAGI PENCIPTAAN KANDUNGAN KREATIF ISLAM DI MALAYSIA: MENDEPANI PEMBERDAYAAN PENGGUNA
}

\begin{abstract}
ABSTRAK
Kandungan yang dipertontonkan melalui industri kreatif sesebuah negara mesti menggambarkan nilai budaya dan agama negara tersebut. Sebagai salah satu alat bagi pembentukan bangsa, industri kreatif memainkan peranan penting dalam menanam nilai-nilai murni dan mengelakkan gejala-gejala sosial. Objektif kajian ini adalah untuk mengkaji kepentingan dan perkembangan kandungan yang berunsur Islamik di dalam industri kreatif Malaysia. Dengan menggunakan kaedah penyelidikan kualitatif, iaitu analisis kandungan dan wawancara, kajian mendapati terdapat peningkatan terhadap permintaan untuk kandungan-kandungan Islamik. Kajian ini bertujuan untuk mengetengahkan beberapa isu yang dikemukakan oleh keduadua pembikin dan pengguna kandungan-kandungan kreatif dengan harapan untuk memperkasakan pengguna dalam memilih kandungan yang lebih bersesuaian dengan keperluan budaya dan agama mereka.
\end{abstract}


Kata kunci: Pemberdayaan pengguna, industri kreatif, penciptaan kandungan, nilai-nilai Islam, penciptaan kandungan berunsur Islam

\section{INTRODUCTION}

The rapid evolution and development of digital technology has allowed many contents to be disseminated and conveyed globally through the most convenient means, digital media. This has led to the development of the creative industry which has attracted a wide range of consumers, i.e. audiences. Examples of creative products are films, drama, animations, songs and others. It is a very common medium for the modern consumers to relieve their stress from the hectic life, for example by enjoying films and dramas at the end of a hectic day at work.

Nevertheless, due to a rise in negative contents on the mass media and the internet, a Content Code was agreed by the service providers, "which sets out the guidelines and procedures for good practice and standards of content disseminated to audiences in the communications and multimedia industry in Malaysia". This comprehensive Code was drafted by the Communications and Multimedia Content Forum under sections 212 and 213 of the Communications and Multimedia Act 1998, an industry body representing relevant sectors of the industry to ensure that the Code reflects the views of the community at large. The Code seeks to identify what is regarded as offensive and objectionable while spelling out the obligations of content providers within the context of social values in this country. The code, which is a blueprint of selfregulation, is drafted purely by an industry society with no interference from the government. This enables the government to keep up with its promises to steer away from intruding into the internet. ${ }^{1}$

Though the purpose of the industry was initially to disseminate important messages to the public at large, however rapid evolution of the industry had brought the creation and promotion of content that pose negative influences to the public. Amongst others, the internet is now a primary means to spread harmful, ethically wrong, maleficent content

\footnotetext{
${ }^{1}$ Ida Madieha Azmi, "Content Regulation in Malaysia: Unleashing Missiles on Dangerous Web Sites," Journal of Information, Law and Technology 3 (2004), https://warwick.ac.uk/fac/soc/law/elj/jilt/2004_3/azmi/.
} 
such as violence, pornography and even propagation of dangerous as well as violent notions such as terrorism. Young adults and children are vulnerable to the elements of violence, pornography and terrorism which are readily accessible on the open media especially if they lack a stable social support network. This may lead to the promotion of a culture of crimes and other social illnesses among the society. These consumers should be protected and inculcated with the right mind set in making the right choices in order to ensure that the content that they choose increases their quality of life. A wonderful idea by Mohamad Md. Yusoff highlighted that, "Films are not only mirrors for the taste of the filmmakers, but also have the power to move and change the orientation, attitude and behaviour of this modern community."2

It is posited here that amongst the contents that can inculcate positive values are Islamic contents which are universal in nature. Recent studies in Malaysia had shown that there is an increase in the demand for Islamic contents in current show business industry. ${ }^{3}$ Nevertheless, these Islamic contents should be transformed to be more contemporary and engaging. This is to attract more audience which has been fed with other more attractive genres, like animations, action thrillers and romantic comedies. In Malaysia, there are increasing numbers of Islamic based TV stations, radio channels and songs. For instance, TV Al-Hijrah, Astro Oasis, radio channel Zayan FM, as well as many new modern and contemporary nasyid singers, for instance Lah Ahmad, Raqib Majid etc. Bearing in mind the fact that for these great efforts to realise its vision, government's support and efficient legal framework can really assist in these initiatives relating to contemporary Islamic contents.

The objective of this study is to highlight the need to increase the production of Islamic creative contents to be promoted and marketed to the global world by using the digital mainstream media. This can be beneficial not only for the development of the human values of the

${ }^{2}$ Mohamad Md. Yusoff, "Dasar Perfileman Negara Sekadar Mimpi?," in Media Dan Masyarakat Satu Kumpulan Esei (Dewan Bahasa dan Pustaka, 1992).

${ }^{3}$ Rosmawati Mohamad Rasit, "The Position of Religious Malays Films in Malaysia from the Perspectives of Islamic Da 'Wah," Jurnal Al-Hikmah 4 (2012): 148-60,

https://www.academia.edu/6051903/The_Position_of_Religious_Malays_F ilms_in_Malaysia_from_the_Perspectives_of_Islamic_Dawah. 
country, but it could eventually contribute to the country's digital economy. As for the contribution of Islamic contents towards consumer empowerment, the consumer in the content industry i.e. the audience may be empowered by having the awareness to choose more spiritual and humanity valued contents which can guide and enlighten them towards prosocial behaviours. This will lead to a more positive atmosphere where the consumers will not be surrounded by negative influences like violence, obscene and heavily hedonistic cultures. Consumers will have more options of creative contents to choose from as compared to just having the entertainment only for the sake of entertainment without the spiritual enrichment aspects.

As for the contribution of the Islamic contents to the digital economy, this can be seen from the success of countries promoting Islamic and humanity contents like Iran and Indonesia, winning awards in international film festivals. Since Malaysia is promoting itself as a Halal hub and a country practicing the wasatiyyah principles of moderation, these Islamic contents can be a great opportunity to disseminate its Islamic cultures and values to the global world which is in dire need of some spiritual enrichments. Generally, these contents can be used as a medium to propagate the right understanding about Islam as a countermeasure towards Islamophobia and to bring more people and audience closer to the true teachings about Islam.

In dealing with these issues, the article is divided into six parts. The first part of the article concentrates on a brief extrapolation of how the consumers are affected by the current creative industry content. In this part, a definition of the word "creative content" is discussed. From there, the discussion continues with an explanation of Islamic creative content and its development in Malaysia and elsewhere. This brings the article to the second part which highlights the reasons as to why there is a demand for Islamic creative contents. Meanwhile, part three of the article brings into focus the position of Islamic creative contents in Iran \& Indonesia, which are well known as producers of many Islamic creative contents in various forms. This enables a comparison to be done on how these areas can be effectively developed in Malaysia. The next part of the article, part four then deals with the guidelines on Islamic content and relevant legislative framework and government policies. The completion of this part leads to the recommendations and conclusions which can be found in the fifth and sixth part of the article. 


\section{CONSUMERS IN THE CREATIVE CONTENT INDUSTRY}

The creative content industry is a booming industry and culture plays a prominent role in the content creation. Some apparent examples are the Hollywood in the United States and the Bollywood in India. Audience are now not only consuming these creative contents through the television, cinema and radio, but they are also able to access it through the internet by watching it online.

The 'creative industry' involves "activities which have their origin in individual creativity, skill and talent and which have the potential for wealth and job creation through generation and exploitation of intellectual property." ${ }^{4}$ Though the creative industry covers a wide range of activity from fashion, fine arts and cultural produces, this study will only focus on the creative content industry, for example, production of film, TV drama, animation etc.

Consumers in this industry will generally be the audiences or the viewers. However, this industry also involves a lot of other entities such as production houses and crews, artists, TV stations, broadcasting companies as well as the marketing and promotions side of the show business. All these will be impacted by any changes made to the creative content industry as they are the main suppliers of the contents to the audiences. Yet, this study focuses on the interest of the audiences as they are the end users of the contents and the development of the society will be impacted by the type of contents and genres served to them.

How consumer empowerment can be achieved through this industry is by giving some guidance to the audiences to decide and choose which contents are suitable for their mind building and development of the right cultures and virtues in the society. This must come hand in hand with the supply provided by the content suppliers as mentioned above. This also means that the suppliers must also provide contents (films, dramas, animations etc.) that could lead to the right mind building and virtue development.

${ }^{4}$ Creative Industries Task Force (CITF) Mapping Document, (1998). 
'Islamic creative contents' can be seen asany creative products that relates to Islam. ${ }^{5}$ This would involve not only the religious-based teachings like tauhid, fiqh and muamalat, but also other humanity values which are universal across all religions. For example, the promotion of peace and prevention of war, respectand appreciation towards other human beings and creatures (animal, mother nature etc.), integrity and some other values relating to the family institution. The holy Quran clearly emphasises that Islam supports pro-social values, as Islam is derived from the word 'Salam' that means peace.

'Contemporary Islamic contents' can be related to modern contents having the elements of Islam and adhering to the Islamic principles to be broadcasted and as a supply for the show business industry. Islamic principles can be associated with messages, actions, visuals, music, choice of words and scripts that are positive in nature and within the framework of Syara'. As mentioned above, the main reason for the need to transform the Islamic contents to make it more contemporary is to attract more audiences (especially the young ones, non-Muslims etc.) to bring them to the right teachings of Islam.

Apart from recent studies that show the increase in the interest towards Islamic contents, the general behaviour among the audiences or viewers is that there is still a preference shown towards action, horror, romantic and comedy movies. ${ }^{6}$ Only minority of the viewers are open to mind building genres for instance documentary, religious, historical and cultural based events. Several producers are courageous enough to bring forward these genres, however these programmes failed to get high rating, what more to reach box-office. This is among the reasons why the film producers usually follow the demand of the consumers by producing films that can appeal the audience. Unfortunately, this is not beneficial to the public as it defeats the true purpose of mass media as a medium to build a holistic society, in terms of education and intellect, moral values and good akhlaq (virtues). Due to the demands of the majority, this role is therefore underutilized. Below is the percentage of existing contents in the local broadcasting industry (Table 1):

${ }^{5}$ Roaimah Omar, Hasan Bahrom, de Mello, Geraldine, eds., Islamic Perspectives relating to Business, Arts, Culture and Communication, (Springer, 2015).

${ }^{6}$ Rosmawati Mohd Rasit, "The Position of Religious Malays Films in Malaysia from the Perspectives of Islamic Da'wah.” 
Table 1

Total and list of genre and sub-genre Malay fiction films (2005-

\begin{tabular}{|l|c|c|c|c|c|c|c|}
\hline \multicolumn{7}{|c|}{$2010)$} \\
Fenre/Subgenre & 2005 & 2006 & 2007 & 2008 & 2009 & 2010 & Total \\
\hline Action & 2 & 1 & 1 & 1 & 0 & 2 & 7 \\
\hline Comedy & 3 & 4 & 1 & 5 & 4 & 2 & 19 \\
\hline Drama & 2 & 4 & 3 & 6 & 2 & 3 & 20 \\
\hline Love & 1 & 1 & 1 & 0 & 2 & 1 & 6 \\
\hline Horror & 1 & 0 & 1 & 3 & 4 & 4 & 13 \\
\hline Animation & 0 & 0 & 1 & 0 & 1 & 0 & 2 \\
\hline Patriotic/History & 0 & 0 & 1 & 0 & 1 & 0 & 2 \\
\hline Comedy/Action & 1 & 2 & 0 & 1 & 1 & 4 & 9 \\
\hline Comedy/Love & 3 & 2 & 4 & 2 & 0 & 4 & 15 \\
\hline Comedy/ Horror & 1 & 0 & 1 & 1 & 1 & 2 & 6 \\
\hline Comedy/Science & 1 & 0 & 0 & 0 & 0 & 0 & 1 \\
\hline Comedy /Musical & 1 & 2 & 0 & 0 & 2 & 0 & 5 \\
\hline Comedy/Fantasy & 0 & 0 & 0 & 2 & 2 & 0 & 4 \\
\hline Comedy /Drama & 0 & 2 & 0 & 0 & 0 & 2 & 4 \\
\hline Comedy/Adventure & 0 & 0 & 0 & 1 & 0 & 0 & 1 \\
\hline Comedy/Mystery & 0 & 0 & 0 & 1 & 0 & 1 & 2 \\
\hline Drama/ Love & 0 & 1 & 0 & 0 & 0 & 0 & 1 \\
\hline Drama/Action & 0 & 0 & 1 & 0 & 0 & 0 & 1 \\
\hline Drama/ Horror & 0 & 0 & 1 & 0 & 0 & 0 & 1 \\
\hline Drama/ Musical & 1 & 1 & 1 & 0 & 1 & 1 & 5 \\
\hline Musical / Love & 1 & 0 & 0 & 1 & 2 & 2 & 6 \\
\hline Horror / Mystery & 1 & 1 & 4 & 0 & 1 & 0 & 7 \\
\hline Horror /Scary & 0 & 0 & 0 & 1 & 1 & 0 & 2 \\
\hline Musical/Fantasy & 0 & 0 & 0 & 0 & 0 & 1 & 10 \\
\hline TOTAL & 19 & 21 & 21 & 25 & 25 & 29 & 140 \\
\hline
\end{tabular}

Source: Rasit (2012) Adapted from FINAS (2005-2010) 
Another contributing factor is that mind building genres would generally require higher cost to ensure high quality products, such as high-quality cameras, crews, artistes and it consumes a longer time to be produced. Moreover, these genres, if done without proper planning and thought usually end up with a piece which is boring and dull, as 'thinking movies' requires the audience to think deeper to appreciate the meaning and the message put forward to them. These low-quality productions are known especially among the government-based broadcasting station as opposed to the private broadcasting companies. The feedback received from the interviews conducted with the respondents from the industry reflected that this is probably due to the complacent culture practiced by the government agencies as the funding is secured and provided by the government. As opposed to the private production houses and broadcasting stations where they have to compete by giving the best quality of content to attract consumers as the customers who pay for their service and survival.

Therefore, it is observed that issues relating to consumers in the Malaysian content industry is based on a two-way relationship. On the one hand, the mind set and preference of the society that tend to choose non-character building film genres and on the other hand, the supplier is also providing non-developing film genres. This symbiosis should be altered by educating the society to choose good genres that can help the nation building and at the same time production houses and broadcasting companies should also supply more intellectual and moral based film genres. In order to support this idea, the government should assist and the legal framework should be enhanced to lay a platform for these efforts to succeed. According to the Performance Management \& Delivery Unit (PEMANDU) of Malaysian Prime Minister's Department in its Economic Transformation Programme (ETP) handbook (2010), "Beyond GNI benefits, this creative content EPP (entry point project) will help preserve Malaysia's unique culture and heritage for the 21 st century and future generations". In line with this aspiration, the government should promote Islamic contents which are part of Malaysian culture, heritage and most importantly, our way of life. In this report, it indirectly alluded that Islam should be the primary consideration for the development of creative content in Malaysia. 


\section{DEMAND FOR ISLAMIC CREATIVE CONTENTS}

Islamic creative contents are among the suggested genres to inculcate good values and virtues through the mass media. How can these Islamic contents be used as a means to achieve the above said consumer protection? This is due to the fact that Islamic teachings can be universally accepted as it promotes enjoining the right and forbidding the wrong. This can be practised even by other religions as the nature of human being would prefer peace and harmony as opposed to evil and chaos. Therefore, Islamic creative contents should be marketed and aggressively introduced to the public at large to substitute the negative influences brought by the mass media. These can be considered as the halal contents for the consumption of the audiences.

There is a study on the demand for Islamic based contents and its relationship with building good cultured society. According to the author Rosmawati Rasit, "the higher the level of watching the Islamic based films among the audience, the higher their pro-social personality is" ". Her study revealed that "the percentage of the respondents who have interests and are fully interested in watching Islamic based films is 85.3 percent. This proves that the future of producing Islamic based films in Malaysia is bright. This is because the audience of Malaysian films also support these kinds of films beside films of other genres." The distribution of level of interest towards Islamic based films is illustrated by the following table (Table 2):

Table 2

Distribution of Level of Interest towards Islamic based Films

\begin{tabular}{|c|l|c|c|}
\hline \multicolumn{2}{|c|}{$\begin{array}{c}\text { Interest level towards Islamic based } \\
\text { films }\end{array}$} & Frequency & Percentage \\
\hline 1. & Very interested & 249 & 24.2 \\
\hline 2. & Interested & 628 & 61.1 \\
\hline 3. & Not interested & 129 & 12.5 \\
\hline 4. & Very not interested & 22 & 2.1 \\
\hline & Total & 1028 & 100.0 \\
\hline
\end{tabular}

${ }^{7}$ Ibid. 
Source: Rasit (2012)

From this finding on the interest level obtained from the respondents, movie makers should grab this opportunity to produce more Islamic contents. This is due to the fact that the production of films in Malaysia is imbalanced in terms of genre. The number of Islamic contents in Malaysia is relatively lesser compared to other genres. This coincides with Abd. Aziz's opinion where he appeals that "it's about time that we increase and bring to the centre films that contain Islamic and humanity elements so that it is balanced with 'tasteless films' that we could find in the market now." 8

Is there such thing as Halal Islamic creative contents? This would refer to the permissible contents according to Hukum Syarak. What is then permissible to be accepted as Islamic contents? This would require some basic guidelines to determine which contents are Halal or Islamic or permissible in the eyes of Islam and which are not. Some basic guidelines had been prepared by the Department of Islamic Development Malaysia (JAKIM).

\section{POSITION OF ISLAMIC CREATIVE CONTENTS IN IRAN \& INDONESIA}

Some jurisdictions like Iran and Indonesia are among the well-known pioneers in providing and supplying Islamic creative contents. How did they manage to excel in promoting these spiritual, religious, humanity valued contents? What are their factors for success? What are the guidelines that they use to monitor and enhance their Islamic content films? These points can be extended in future studies to discuss on these factors and strategies in detail.

Among the findings on the film industry in these countries is the birth of "a phenomenon of movies produced in Indonesia and Iran that has made the Islamic movies a great prestige such as Dalam Mihrab Cinta (In Mihrab Love) (2010), Ketika Cinta Bertasbih $1 \& 2$ (When Love

${ }^{8}$ Abd. Aziz Itar, "Perbanyakkan Filem Berunsur Keislaman," Utusan Malaysia, December 12, 2007. 
Says A Prayer) (2009), Children of Heaven (1997) and The Song of Sparrows (2008)." 9

FINAS (2011) statistics showed that between 2005 and 2010, Malaysia produced 140 Malay films from the various categories of genres. According to Rasid (2012), "Sad to say, within this time frame none of the films discussed the elements of religion as the main issue of what Muslim directors and scriptwriters should fight for in Malaysia. On the other hand, they prefer to adapt the western genres that conflict with our cultural value and religion. For that, Malaysians have seen films like Anak Halal (Legitimate Child), Bohsia...Jangan Pilih Jalan Hitam (Bad Girl...Don't Choose Bad Direction), V3...Samseng Jalanan (V3...Road Gangster) and other films that have Western element as their background."10 These films portray negative influences, like drug businesses, wild lifestyle among the teenagers as well as prohibited relationship between man and woman that leads to the existence of illegitimate child. Adam Salleh lamented, "We are so busy in making and producing fiction, romance, action 'drift' films, until we overlooked on how desperate we are in making films that hold the purity of Islam."11

These are amongst the ground work that Malaysian industry players and the government can look into and work hand in hand to adopt these strategies and mechanisms in order to also succeed in producing Islamic contents and strengthen its position as a wasatiyyah Islamic country and make full use of these contents to further contribute to our digital economy. This can be a distinct Malaysian feature in the massive world digital economy as there are very few countries that are really serious in their efforts to promote Islamic creative contents.

Another important aspect is the internationalisation of Malaysian Islamic creative content industry. There is enormous potential to be grabbed especially in the Islamic media and recreation market with continuously expanding number of Muslims demanding for films and TV programmes, music and educational programmes that reflect and adhere to Muslims' cultural and religious values. Thomson Reuters reported that the combined spending of Muslims around the globe on media and recreation will grow from $\$ 185$ billion in 2013 to $\$ 301$ billion in 2019 .

\footnotetext{
${ }^{9}$ Rosmawati Mohd Rasit, "The Position of Religious Malays Films in Malaysia from the Perspectives of Islamic Da'wah." ${ }^{10}$ Ibid.

${ }^{11}$ Adam Salleh, "Tandus Filem Agama," Harian Metro, April 20, 2008.
} 
The Global Islamic Economy Indicator 2017 Report projects that the Islamic economy will be worth US\$3 trillion by 2021 .

\section{GUIDELINES ON ISLAMIC CONTENT AND RELEVANT LEGISLATIVE FRAMEWORK AND GOVERNMENT POLICIES}

In Malaysia, like other countries, there is no single legislation that deals with the promotion and development of creative content. Copyright law, which is responsible for the protection of right holders' proprietary and financial interests in content, is content neutral. This is in line with international standards and commitment that mandate all works to be protected regardless of the nature of the content. Historically, copyright has been used to deny protection against works which are deemed to be against religion, public order and morality and public interest. ${ }^{12}$ But that approach is not longer acceptable in many countries as it goes against international norms that mandate the removal of content-based restrictions on copyright-ability. Although copyright cannot be used to deny the rights of the authors and owners but its potential as a means to stop the circulation of certain types of content, including content which are offensive to religion is still being resorted to. In Garcia v Google, ${ }^{13}$ an artist applied for a preliminary injunction requiring the removal from youtube.com, an anti-Islamic film which used a performance that the plaintiff made for a different film. In this case, the artiste's five-minute performance had been transformed by the producer to utter blasphemous proclamation against Prophet Muhammad (s.a.w) which then led to death threats against her and her family. The District Court granted the preliminary injunction which resulted in You-Tube taking down all copies of 'Innocence of Muslims' from youtube.com. On appeal, however, the decision was reversed. In a split decision, the majority of the judges of the US Court of Appeals for the Ninth Circuit rejected her claim on the basis that her 5 minutes performance did not qualify her to claim copyright for her acting performance. The dissenting judgement by Kozinski, however, opined that the dramatic performance met all the requirements for copyright protection and the copyright claim was likely

\footnotetext{
12 Stephens v Avery (1988) 11 IPR 439 (Ch).; Glyn v western Feature Film (1916) 1 Ch 261; Murray v Benbow (1822) The Times 2 Feb. 1822, Stockdale v Onwhyu (1826) 5 B.C. 510.

${ }^{13}$ Cindy Garcia v Google, Inc, No. 12-57302 (9th Cir. 2015).
} 
to succeed. Whilst this case is no authority for the assertion that copyright can be used to deny protection against certain types of work, but it illustrates how copyright is still resorted to in order to frustrate the enforceability of a copyright work when the content is objectionable by any means, particularly religion, public interest, public order and morality. ${ }^{14}$

As Malaysia moves towards the digital economy and with the convergence of media, a single legislation that deals with different types of content is therefore, warranted. This has given birth to the passing of the Communications and Multimedia Act 1998 (CMA 98) and the repeal of previous medium specific legislation such as the former Broadcasting Act 1988 and Printing, Presses and Publication Act 1984. Among the objectives of CMA 98 is to "grow and nurture local information resources and cultural representation that facilitate the national identity and global diversity." The clear reference to national identity indicates that whilst it is not in the interest of the government to censor the internet, nevertheless, the prevailing standards on what is acceptable and not acceptable content should not be totally disregarded. For that purpose, the Communications and Multimedia Content Forum of Malaysia drafted the Content Code to delineate what is offensive and objectionable content. ${ }^{15}$ The Code is applicable to all types of content and the breadth of the definition means it would be applicable to film as well ${ }^{16}$. The Code identifies several types of indecent, obscene, violent, menacing and false content, as well as contents that uses foul language. ${ }^{17}$ The types of objectionable contents are listed in the Content Code and it is submitted here that this is in line with Islamic teachings and precepts and therefore could be useful in the development of Islamic content in

${ }^{14}$ Ida Madieha Abdul Ghani Azmi, "Authorship and Islam in Malaysia: Issues in Perspective", International Review of Industrial Property and Copyright Law, Vol. 28, 671-708.

15 http://www.cmcf.my/download/CONTENT_CODE_(V6-Final).pdf.

${ }^{16}$ Content is defined to mean 'any sound, text, still picture, moving picture or other audio-visual representation, tactile representation or any combination of the preceding which is capable of being created, manipulated, stored, retrieved or communicated electronically'.

${ }^{17}$ Ida Madieha Azmi, "Content Regulation in Malaysia: Unleashing Missiles on Dangerous Web Sites". 
Malaysia. The Code goes further to attest to the special position of Islam as the official religion of the country. ${ }^{18}$

From the discussion, it can be summarised that there is actually no law which prohibits or stops the creation of a specific content except when the content is illegal. From another perspective, there is also no legal framework which promotes any specific type of content. This is the part which the law makers can look into in order to promote the creation of Islamic contents as there is definitely no legal encumbrance to create Islamic content. Among the main purposes to support this initiative is definitely the positive values that can be inculcated through the dissemination of the Islamic contents on the mainstream media.

To ensure that content producers are able to meet the above goals, a guideline known as the 'Guideline for Screening of Islamic Broadcasting Content Materials' was published by JAKIM in 2015. ${ }^{19}$ Among others, the objective of the Guideline is to provide information and awareness to content producers, broadcasters, classification agencies and relevant government departments to ensure contents produced and marketed would be in line with the Ahli Sunnah Wal-Jamaah or the Shafie school of thought. The guideline is summarised in the following table:

Table 3

Summary of the Guideline for Screening of Islamic Broadcasting Content Materials

\begin{tabular}{|c|c|c|}
\hline $\begin{array}{l}\text { Islamic } \\
\text { values }\end{array}$ & $\begin{array}{c}\text { Guiding Principles } \\
\text { (Contents must not have } \\
\text { elements which: -) }\end{array}$ & Examples \\
\hline $\begin{array}{l}\text { Protection } \\
\text { of Muslim } \\
\text { creed } \\
\text { (aqidah) }\end{array}$ & 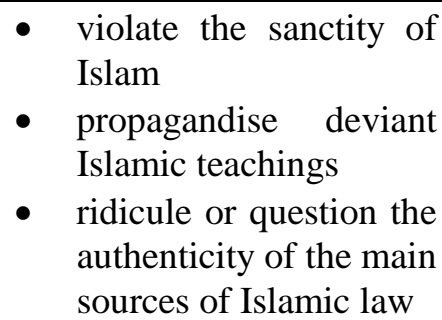 & $\begin{array}{l}\text { - } \text { performing the role of } \\
\text { exhibiting the } \\
\text { illustrations of prophets, } \\
\text { angles, satan and the } \\
\text { Sam'iyyat and } \\
\text { Ghaybiyyat. } \\
\text { - swearing, except by the }\end{array}$ \\
\hline
\end{tabular}

${ }^{18}$ See 3.13 Content Code, available online at http://www.cmcf.my/download/CONTENT_CODE_(V6-Final).pdf.

${ }^{19}$ JAKIM, "Garis Panduan Penapisan Kandungan Bahan-Bahan Penyiaran Berunsur Islam" (2015). 
IIUM LAW JOURNAL VOL. 26 NO.1, 2018

\begin{tabular}{|c|c|c|}
\hline $\begin{array}{l}\text { Islamic } \\
\text { values }\end{array}$ & $\begin{array}{l}\text { Guiding Principles } \\
\text { (Contents must not have } \\
\text { elements which: -) }\end{array}$ & Examples \\
\hline & $\begin{array}{l}\text { - propagandise the belief } \\
\text { of other religion apart } \\
\text { from Islam. }\end{array}$ & $\begin{array}{l}\text { name of Allah } \\
\text { ridicule the Qur'an or } \\
\text { Sunnah }\end{array}$ \\
\hline $\begin{array}{l}\text { Protection } \\
\text { of morality } \\
(\text { akhlaq })\end{array}$ & $\begin{array}{l}\text { - contain immoral } \\
\text { elements against the } \\
\text { teachings of Islam }\end{array}$ & $\begin{array}{l}\text { - A hugging scene } \\
\text { between a non-mahram } \\
\text { man and a woman } \\
\end{array}$ \\
\hline $\begin{array}{l}\text { Protection } \\
\text { of Islamic } \\
\text { Act of } \\
\text { Worship } \\
\text { (Ibadah) }\end{array}$ & $\begin{array}{l}\text { to act out specific acts } \\
\text { of worship wrongly or } \\
\text { to ridicule them. }\end{array}$ & $\begin{array}{l}\text { - A dialogue or action of a } \\
\text { person performing } \\
\text { prayer in an } \\
\text { inappropriate manner. }\end{array}$ \\
\hline $\begin{array}{l}\text { Protecting } \\
\text { human } \\
\text { relations } \\
\text { (hablun } \\
\text { minannas) }\end{array}$ & $\begin{array}{l}\text { - A Muslim to play the } \\
\text { role of a non-Muslim, or } \\
\text { an actor to play the role } \\
\text { of a woman and vice } \\
\text { versa. } \\
\text { - An actor and actress } \\
\text { who are legally married } \\
\text { to act out scenes or utter } \\
\text { dialogues related to } \\
\text { marriage laws. }\end{array}$ & $\begin{array}{l}\text { - Male Muslim dressing as } \\
\text { female and vice versa } \\
\text { - A legally married couple } \\
\text { plays the role of a } \\
\text { husband and wife and } \\
\text { the husband utters words } \\
\text { or sentences indicating } \\
\text { divorce such as "I } \\
\text { divorce you" or } \\
\text { indicating zihar as "your } \\
\text { back is like my mother's } \\
\text { back" and the like. } \\
\text { A scene, action or } \\
\text { translation (subtitling) } \\
\text { which is related to } \\
\text { religions other than } \\
\text { Islam but contains or } \\
\text { uses Islamic words or } \\
\text { terms such as Allah, } \\
\text { Kaabah, Baitullah and } \\
\text { solat. } \\
\text { A scene or action which } \\
\text { indicates that performing }\end{array}$ \\
\hline
\end{tabular}




\begin{tabular}{|c|c|c|}
\hline $\begin{array}{c}\text { Islamic } \\
\text { values }\end{array}$ & $\begin{array}{c}\text { Guiding Principles } \\
\text { (Contents must not have } \\
\text { elements which: }-)\end{array}$ & \multicolumn{1}{|c|}{ Examples } \\
\hline & & $\begin{array}{l}\text { zikr after prayers, } \\
\text { Maulidur Rasul and } \\
\text { performing tahlil for the } \\
\text { deceased are considered } \\
\text { bid'ah dhalalah (heretic } \\
\text { innovation) in Islam }\end{array}$ \\
\hline & & \\
\hline
\end{tabular}

Source: Jabatan Kemajuan Islam Malaysia

Nevertheless, the implementation and adherence to this guideline can be further improved and supported by other legal frameworks and incentives by the government and other entities. This can be seen from the fact that some Malaysian films do not adhere to the guideline, which makes content regulation and enforcement more problematic. Perhaps, the reason for lack of compliance to JAKIM's guideline can be attributed to its voluntary nature.

Another important guideline is the Broadcasting Ethics Code (' $\mathrm{Kod}$ Etika Penyiaran') prepared for Radio Television Malaysia (RTM) which is formulated to preserve the interest of the public audience. The Code should be utilised to the maximum in order to prevent and filter negative influences through broadcast of films or drama, including violent influences, obscene contents and other influences that contradict with Islamic and moral values. The RTM Code is meant specifically for regulation of contents aired through its television broadcasting channels namely TV1 and TV2. The RTM Code embraces similar guiding principles as those found in JAKIM Code, which includes protection of Islamic values. ${ }^{20}$

20“Kod Etika Penyiaran Jabatan Penyiaran Malaysia” (n.d.). 


\section{RECOMMENDATIONS}

To realise these efforts, more initiatives needs to be launched and promoted to boost Malaysian TV and film industry in producing humanity values and Islamic centred products which if made with good quality, will be acceptable at the international market and globally recognized. Amongst the suggestions that can be taken up by relevant agencies and industry players are:

1. Continuous benchmarking studies should be done on strategies of the award-winning contents, for instance how Iran, Indonesia (religious contents), Hollywood, Bollywood, and Korea (box office and high demand creative contents) produce high quality content and able to market their product internationally.

2. Adoption of the strategies discovered from the benchmarking studies supported with government funding and promotional platform.

3. Extensive utilization and enhancements to existing guidelines to incorporate and support these strategies for further progress of Malaysian creative industry (for example, to insert these suggested additions to the existing guidelines which can be improvised: No physical contact between non-mahram and proper covering of aurah for the actors and actresses (especially to avoid scenario where the actresses covers their aurah for scenes outside the house but then opens the aurah for scenes inside the house).

4. Provide special incentives and awards for film makers and producers who come up with Islamic and humanity valued contents to encourage more content makers (producers, directors, scriptwriters and song makers) to produce more Islamic contents works. In the music industry, there are some good examples that can be adopted, for example its 'Anugerah Nasyid' (Nasyid Award). There are two apparent examples for this. The first model is the recent successful collaboration between Institut Kefahaman Islam Malaysia (IKIM) and TV Al-Hijrah. The objective of the award programme was to recognize the talents and efforts of the industry players among others are the composers, lyricist, singers and other players involved in the musical works. ${ }^{21}$ On the other hand, the second instance refers to the

${ }^{21}$ BERNAMA, "10 Lagu Ke Peringkat Akhir Anugerah Nasyid 2017,” BH Online, 2017, https://www.bharian.com.my/hiburan/lainlain/2017/11/355339/10-lagu-ke-peringkat-akhir-anugerah-nasyid-2017. 
one jointly organized since 2004 by 'Sekretariat Anugerah Industri Nasyid', JAKIM, RTM and supported by 'Dewan Bandaraya Kuala Lumpur' (DBKL) which is known as the 'Anugerah Nasyid Minggu Ini (Anugerah NMI)'. These two initiatives have been the contributing factors for the successful emergence of local Islamic talents that uses the entertainment industry as a platform to spread Islamic da'wah to the mainstream audiences. If we realise, those were the times when very impactful nasyid groups were blooming, to name a few, Raihan, Rabbani, Inteam and the list goes on. As a matter of fact, groups like Raihan and Rabbani had taken an extra leap and was internationally recognized by the global music arena. They were invited by organizers to perform in many countries across the globe, either from developed, developing or under developed country. Countries like France, United Kingdom, Spain, Africa and Russia had recognized our local nasyid talents. ${ }^{22}$ This proves that Malaysian content creators can make it if they are to put their hearts and efforts into it. However, that was many years back. How about now? Where have all these talents gone to? Are there no successors to these magnificent achievements by the local nasyid talents? On the same note, not only does the music industry need to improve itself, the film and drama industry should follow the footsteps of the music industry to spread more Islamic $d a$ 'wah to the content industry consumers, locally and globally. The film and drama industry needs to establish an award event for the Islamic content creators. This is to motivate the filmmakers as well as the drama producers in producing quality Islamic contents. At the end of the tunnel, when quality creative works are served to the audience, this can be a marketing platform to bring our local contents to the international arena.

5. Close supervision by a special unit in government agency (JAKIM for instance) to monitor the films categorised as Islamic contents, strictly adhere to Islamic guidelines (for example, no physical contact between non-mahram and proper covering of aurah) and at the same time the storyline has a positive message to be conveyed to the society.

${ }^{22}$ Ridzuan Abdul Rahman, "Rancak Beraksi Di Luar Negara," My Metro, December 22, 2017, https://www.hmetro.com.my/rap/2017/12/295922/rancak-beraksi-di-luarnegara. 
6. The board of screening for example should consist of people in the industry as well as people with Islamic education to ensure the guidelines are properly observed.

7. Special tertiary education in exposing the students to the production of Islamic creative contents, its way forward and some boundaries to boost creativity to work within the Syariah limitations as a means to protect the consumers in creative industry against its negative influences.

8. Promote and conduct campaigns to create awareness and culture among the public and audience to do away from non-intellectual building genres as well as to accept and appreciate heavier genres which is useful for the development of the country and the society.

9. The Organisation of Muslim Countries (OIC) should include promotion of Islamic creative industries in their agenda for economic growth and prosperity of the Muslim countries. Professionals, artists, films and programmes must be allowed to move freely across borders and a platform must be created for the industry players to learn from each other and transfer new knowledge across borders. Exchange of ideas and expertise must be considered as a priority and it will be useful for the Islamic creative content industry to cooperate and produce contents that would attract demand from a wider range of Muslim consumers in the world.

10. Similarly, Muslim countries in ASEAN namely Malaysia have benefitted from low or zero duties for most imports under the ASEAN Free Trade Area agreement. However, what's still pending and sticky is the movement of professional workers within the region. Muslim countries in ASEAN therefore has to facilitate and ease their mobility and there is a need for a clear policy to support Islamic creative industries.

\section{CONCLUSION}

Contemporary Islamic content is very crucial in today's world where some Muslims themselves are still not clear about the true teachings of Islam. What more of the non-Muslims. Sometimes even the non-Muslims understand Islam better than the Muslims. The creative industry (especially films, TV, songs, animation) are the mainstream media to be utilised to spread the true teachings of Islam as it can reach millions of audiences. 
In terms of financing, there is a sharing from advisors of local financiers for instance MARA and SME Bank that offered financing for producers to produce Islamic contents films or dramas. ${ }^{23}$ However, producers need to ensure that they adhere to the guidelines for Syariah compliance. This is to avoid misuse of funding by malpractices amongst producers that will lead to low quality of the Islamic films or dramas. This will eventually lead to a collapse in this newly growing industry. Looking from another spectrum, the Syariah compliance guidelines and legal frameworks also need to be enhanced for better understanding amongst the industry players. This is to avoid criticism from the audience saying that the creative work is supposed to be Islamic in nature but turn out to have negative influences like the touching between non-mahram. In addition, the messages that are intended to be conveyed to the audience also need to be carefully considered in order to maintain the Syariah compliance standards for these Islamic contents.

Finally, Muslims should take this opportunity to fully utilise the digital technology for the benefit and betterment of the Ummah, to bring them closer to their Creator. The government should also support this move by providing initiatives, grants as well as putting into place a legal framework to ensure the success of these efforts.

\footnotetext{
${ }^{23}$ Mohd. Naim Aziz,"Industri Kreatif Perlu Patuh Syariah Untuk Dapat Pembiayaan Mara," Utusan Online, October 3, 2015, http://www.utusan.com.my/berita/nasional/industri-kreatif-perlu-patuhsyariah-untuk-dapat-pembiayaan-mara-1.142271.
} 